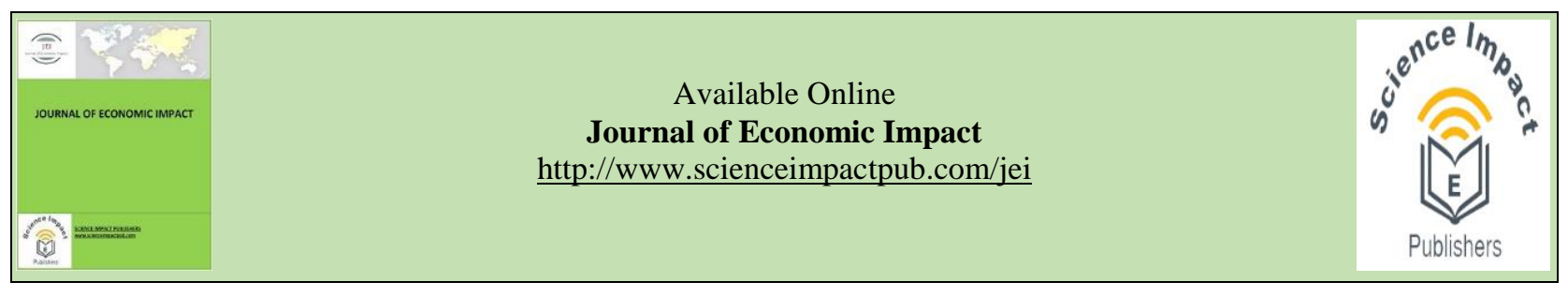

\title{
INTENTIONS TO URBAN MIGRATION AMONG YOUTH: A CASE OF DISTRICT KHUSHAB OF PAKISTAN
}

\author{
Ifat Urooj ${ }^{\text {a,* }}$, Iqbal Javed ${ }^{\text {a }}$, Shahbaz Ahmad ${ }^{\text {b }}$ \\ ${ }^{a}$ Department of Economics, University of Lahore, Sargodha-Campus, Sargodha, Pakistan \\ ${ }^{\mathrm{b}}$ Department of Education, University of Lahore, Sargodha-Campus, Sargodha, Pakistan
}

\section{HIGHLIGHTS}

- The availability of health facilities has a significant and negative impact on determining the youth's intention to migrate.

- Satisfaction from educational facilities has a significant and negative role in the intention to migrate among rural youth.

- Results of satisfaction from job facilities also have a significant and negative impact on the intention to migrate among the youth of rural areas.

- Satisfaction from business facilities also has a significant and negative effect on the intention to migrate among youth.

- The increase in earning opportunities in rural areas reduce migration intentions. In order to reduce migration intention among youth government should regulate reforms regarding the distribution of resources to increase incomes of rural residents.

\begin{abstract}
The role of migrants on economic downfall in the case of developing countries has been recognized by the researchers and the policymakers. As it becomes difficult for the policymakers and the local government to manage and organize economic activities with the new arrival of migrants from rural to urban areas. The problem of congestion, health and residence issues, are also caused by migration. So this study investigates the impact of socio-economic and demographic indicators on migration intention among the youth of district Khushab. The results obtained from this study show that there are some economic and non-economic pull and push factors that aspire the young generation to migrate from rural to urban and urban to urban areas. Positive association of migration intention with income, assets, age, and education, already migrated members of households and already migrated friends or relatives have been observed. While there is a negative association of land, satisfaction from education facilities, satisfaction from job facilities, satisfaction from transport facilities with migration intentions. Marital status shows that a married person is less likely to migrate due to family obligations. Due to underlying problems caused by migration the study suggested that equal distribution of resources should be materialized. Special attention should be given on the provision of health, education, job, and transportation facilities in rural areas to alter migration intention among youth.
\end{abstract}

Keywords: Migration intention, pull factors, push factors, socio-economic, developing countries, congestion, Pakistan.

Received: April 17, 2019; Accepted: Dec 30, 2019; Published: April 28, 2020.

* Correspondence: Department of Economics, University of Lahore, Sargodha Campus, Sargodha, Pakistan

Email: iffaturooj137@gmail.com

\section{Introduction}

The problem of rural to urban migration is a relatively old and widespread phenomenon at a global level. However, from a few recent years, it has become a cause of great concern at the regional, national and global levels. The unparalleled levels of urbanization characteristic of most developing countries have resulted in the movement of people from rural to urban areas, resulting in the emergence of informal settlements and slums. Growing developmental challenges that include the spread of disease, provision of unclean water, poor infrastructures, poor service delivery, and insecurity are common in developing regions. Furthermore, problems such as congestion, pollution, and crime are linked to this concept (Siddiqi, 2004). Despite all above mentioned alarming facts, rural to urban migration is also 
sometimes seen as an important lively-hood strategy for rural youths mostly domiciled in poor rural areas in developing countries. In about 10 years, nearly half of the population in Pakistan is set to live in cities compared to one-third today. Analyst Kugleman (2014) talked about the South Asian nation's major challenges.

Several theories explain why rural to urban migration takes place. Among these theories, the Harris \& Todaro (1970) model is the best one. This model explains that migration takes place due to the wage differential between rural and urban areas (Harris and Todaro, 1970). They are also of the opinion that the decision to migrate as an individual decision. A study by Agesa and Kim (2001) improved this model. They argued that migration is a family decision rather than an individual decision. They focus on household units maximizing their utility through different forms of migration. Their study observed that family consists of large members as dependent, majority engage in split rural to urban migration, mostly household head temporarily migrate to an urban area without his family and after having sufficient income stay in an urban area. Literature by Tang \& Hao (2018) on return intentions of China's rural migrants suggested that most of the people have the intention not to reside in the host city permanently; a large group of people intended to get back to the home town or city rather than to home rural region. The decision to get back is highly based on family obligations. Their study has two major findings, first is, a trade-off between livelihood in the rural origin and the urban destination and second is, intention or goal to maximize utility depends upon the family background and the available resources, which induce a migrant to migrate in the urban region close to the home region. Wang et al. (2014) revealed the fact that there is a disparity between young migrants and their older ones, Young people concerned with their socioeconomic status and social capital while their old counterparts are compelled by the age, family obligations, and occupational skills. In addition to this access to housing and emotional effectiveness of the migrants plays a decisive role to stay or leave intention.

Pakistan by its geography has been defined as a country for a long time. The majority of its population is based and the largest industries are installed. It is a country that is urbanizing at the annual rate of three percent, the fastest speed in South Asia. Kotkin et al. (2013) argued that highly dense populated cities like Karachi are facing rapid urbanization; an increase in the population growth of Karachi is about $80 \%$ from (2000 to 2010). The estimates of (The United Nations Population Division) predicted that, as compared to one-third today, almost half of the population of Pakistan will set to live in cities by 2025. Cities are the focal point of Pakistan's prominent educational institutions that transmit education, research and development, training, skills, and opportunities in commercial restraining. But if on the other hand, urbanization is not properly managed it may lead to an extensive burden on the formally rushed labor market, and seriously analyze the state's ability to facilitate people with crucial services in the cities. No doubt today, but also for the upcoming 10,15, and 20 years when the urban population of the country would be doubled, the efforts to provide housing, clean water, electricity, clean water, health care services, transport, and infrastructure will become a broader challenge. Deficiency or failure to meet these tasks of human development could lead to an urban population of Pakistan less efficient participants of the society as well as the economy. There are two main causes of rapid urbanization in Pakistan which are characterized by a sharp increase in population growth rate and internal migration trend of people (Abdel- Hamid, 2009).

According to statistical measures of Kugleman, (2014) total population of Pakistan is increasing at the rate of $3 \%$ per year and if this rises continuously, the population growth rate will increase from 180 today to (380) million till 2050. Some other factors from rural to urban migration include cultural conflicts and war. When partition between India and Pakistan took place in 1947, millions of Muslims migrated from India to urban areas of Pakistan and rushed in provinces of Punjab and Sindh. Similar inflow occurred during the Indo-Pak war in 1965 and 1971. During the anti-Soviet Revolution in 1980which below up in Afghanistan, a large number of Afghan masses came to set in the cities of Peshawar and Quetta the western areas of Pakistan. More recent few years, military insolent in tribal areas of Afghanistan and Pakistan have provoked migration of people to Pakistani cities particularly to Karachi, Peshawar, and Quetta. Others are migrating to urban areas in search of a better quality of life including, employment and education and healthcare, opportunities that are more often accessible in urban regions.

A decision regarding Motivation and intention to migrate from rural to urban area grow more diverse in a rapidly changing world, where migration is made easier by expanding transportation and communication, informational resources. The literature categorizes migration into two types, motivations that propel long term (permanent) migration, and short term (temporary) migration (De Jong, 2000). This distinction could not deny the fact that temporary migration sometimes becomes permanent and permanent migration due to a variety of intervening factors short cut. There are some other dimensions as well behind the complexity of decisions and preferences. Like, individuals may have different 
degrees of certainty regarding their future and the role of migration in that future. Some people have a definite plan to migrate while others have the intention to migrate just for the sake of fun only, without any specific plan or objective.

Another dimension is to have migration preferences and decision that is defined by the characteristics and the number of people who farm unit of migrant. In this case migration by individuals is compared with migration that involves family members (Yang, 2000; Root and De Jong, 1991; and Boyd, 1989). Similarly, the intention to move individually and with children and family can be compared. In this study, we will simply know about migration intentions among youth, their migration preferences and to relate possible differences of psychological and socioeconomic factors. Economic literature also points out that lack of employment, job facilities, draught famine, poverty, landlessness, hope to find a job, increase income, educational opportunities, better jobs and services and enhancing one's socioeconomic status increase the intention to migrate urban areas (Macharia, 2003). The study of migration reveals those friends and the people known to us who have already migrated or have the intention to migrate influence in migration intention and decision (Epstein and Gang, 2006). According to Sosne et al. (2002) and Kloep et al. (2003) communities integrated tightly, offer less freedom of recreation and opportunities to explore social and individual identities. A structural model of youth's migration is developed with these considerations determined by individual sources, economic interests, individual identity, and social context. Migration intention encouraged by the interpersonal ties like friendship, kinship, shared community of origin, between migrants, new and former migrants and nonmigrants from origin and destination both are included in this context. Migration intention and decision is also affected by the perception about the socioeconomic and political circumstances of the origin and the destination of migration (De Jong et al., 1985; Austin and Richter, 2005; Stinner and Van, 1992). This study focused on the migration intention of youth in district Khushab.

The majority of people in Pakistan live in the countryside, with only one- third of the country's estimated 188 million inhabitants currently in cities. But things are changing rapidly. Pakistan is urbanizing at an annual rate of three percent, the fastest pace in South Asia. The United Nations Population Division estimates that by 2025 nearly half the country's population will live in an urban area. Increasing urbanization has posed various kinds of developmental challenges to urban areas because of increasing pressure on social services such as housing, health, water, and education (Huggins et al., 2005).
Rural to urban migration could have a negative impact on agricultural productivity due to the limited availability of labor. Because of these possible negative impacts of rural to urban migration, there was a need to conduct research to identify the causes of this phenomenon as there is a dearth of information on this topic. This study will explore underlying factors that influence the majority of youth to have the intention to migrate rural to an urban area. This study will also suggest some policy measures and guidelines to Government to reduce migration intentions among youth and to focus on the proper distribution of the suggested economic resources. In this way, not only economic wellbeing of youth would be achieved but the efficient allocation of resources would also be materialized.

\section{Methodology}

\section{Sampling and Data}

Random Sample of 350 young people having age (16-30) is collected from the rural and urban areas of Khushab district. In which, three Tehsils; Khushab, Quaidabad, and Noorpur Thal were selected for the data collection. The study was conducted and organized within the period of 2 months from September 2018 to October 2018. Different methods were used to collect primary data like qualitative, quantitative and participatory procedures. Open and closed-ended questions were asked from young respondents through interview and an organized questionnaire was exercised by them for data collection. To make this study more robust and more authentic, data collection is materialized through an ordered and well-organized questionnaire which is comprised of a mixture of closed-ended and openended questions. For data collection, there are two sampling techniques, non- probability and probability technique. The non-probability technique was utilized as the total population migrating to cities was not known. Data was collected from district Khushab and the sample size taken was 350 respondents. In which 175 respondents are from urban area and 175 are from rural areas. In these respondents 88 were male and 87 female respondents were from each area. At the initial stage, the province of Punjab was selected as it is the most diverse and populated province of Pakistan.

In the second stage, district Khushab was selected as it was convenient for the author to collect data from district Khushab. Khushab is not only a city but also a district of province Punjab. Khushab is located near Jhelum River, between Sargodha and Mianwali (the cities of Pakistan.On third stage three Tehsils Quidabad, Kushab and NoorpurThal were selected. At the fourth stage, 2 villages were selected from Khusahab and Quaidabad, and 1 village from Noorpurthal, 1 urban area was selected from each 
Tehsil. At the fifth stage, male and female respondents from villages and towns of each Tehsil were randomly selected for data collection.

\section{Binary Logistic Regression Model}

When studying the determinants of migration, a variety of methodologies can be used. Holst \& Schrooten (2006) analyzed the probability of migration decision using probit or logit model which also named as probabilistic method or logistic regression. When the dependent variable is dichotomous these techniques are commonly used by most of the researchers. This study used a binary logistic regression model for econometric analysis, it is applied to determine socio-economic and demographic factors affecting the intention of migration among the youth of district Khushab. In the logistic regression model, the variable to be regressed is commonly dichotomous, if there is the success of probability it takes the value 1(q), or o (1-q) otherwise.

In this study, the binary dependent variable in the model is the probability of a person to emigrate. In our analysis, the chance or probability of migration intention of a young person is a binary dependent variable. Here we assumed the value of a binary dependent variable $(\mathrm{y})$ which is coded as $0 / 1$; the value 1 indicating the happening of an event, so on the base of values given in independent variables the model determines the probability of occurring this event. This study followed the method used in the study of Roman and Vasilescu (2016).

Hence the model's general form is:

$$
\begin{aligned}
& \ln \left[\frac{\rho}{1-\rho}\right]=\beta_{0}+\sum_{i=1}^{k} \beta_{i} x_{i}+\varepsilon, \text { where } \rho \text { is } \\
& P\left(y=1 \mid X_{1}, X_{2} \ldots \ldots, X_{K}\right) \ldots \ldots \text { (1) }
\end{aligned}
$$

The interpretation of $\beta \mathrm{i}$ coefficients is that, the increase of logit (logarithm of OR) when xi increases by 1 (provided that the other variables are taken as constant).

The model can be written as

$$
P\left(y=1 / x_{1}, x_{2}, \ldots x_{k}\right) \frac{\exp \left(\beta_{0}+\beta_{1} x_{1}+\cdots \beta_{k} x_{k}\right)}{1+\exp \left(\beta_{0}+\beta_{1} x_{1}+\cdots \beta_{k} x_{k}\right)} \ldots
$$

After simplifying this equation we get

$$
\exp \left(\beta_{\circ}\right) \frac{P\left(y=\frac{1}{x_{1}}=x_{2}=\cdots=x_{k}=0\right)}{P\left(y=\frac{0}{x_{1}}=x_{2}=\cdots=x_{k}=0\right)} \ldots .
$$

i.e OR for $\beta$ i Coefficient when all the factors set to (0)

$$
\frac{P\left(y=\frac{1}{x_{i}}=1, x_{j} 0 \text { for } j \neq i\right)}{1-P\left(y=\frac{1}{x_{i}}=1, x_{j} 0 \text { for } j \neq i\right)} \times \frac{1}{O R_{\text {base }}}=\frac{O R_{x i=1, x j=0}}{O R_{\text {base }}} \ldots
$$

Hence due to the multiplicative form of the logistic model, we can have:

$$
O R_{x 1, x 2, \ldots x k}=\exp \left(\beta_{\circ}\right) x \prod_{i=1}^{k} \exp \left(\beta_{i} x_{i}\right)(5)
$$

The meaningful interpretation is that each $\beta \mathrm{i}$ tells about the contribution of factor xi in describing the probability (as or) of event i.e $\mathrm{Y}=1$.

Thus by putting $\mathrm{Xi}=1$, exp $(\beta \mathrm{i})$ would be multiplicative constant factor, irrespective of the values of other explanatory variables.

If $\beta i=0$, it means that the corresponding variable has no effect (multiplying with 1 ).

If $\beta i<0$, it means that presence of the variable will reduce the probability of an event $Y=1$.

If $\beta i>0$, it means that the presence of factor will increase the likelihood of the event.

\section{Description of Variables}

In the present years, researchers have great concern in analyzing the aptitude, attitude, and behavior of youth's migration intention. So the main aim of this research is to find the factors affecting the intention to migrate among the youth of district Khushab, therefore dummy variable is used which shows value 1 if a respondent has intention to migrate and variable contains 0 value if the respondents have no intention to migration. In this study the econometric model used some important variables while going through a deep review of the literature. These variables include socioeconomic and demographic variables (social status, age, gender, residence), variable giving consideration of human capital (level of education) as shown in Table 1.

Age: Tells about the age of respondents in years from the date when interview is conducted.

Gender: Gender is containing binary value, 1 value for the male respondents and 0 for female respondents. Residence: Residence is also a binary variable containing 1 value if the respondent is resident of urban area and 0 values for rural respondents.

Income: Income tells how much money a respondent earn in term of Pakistani rupees. In this study, income is measured in thousand rupees.

Family Assets: This is an economic indicator of a person so in this study family asset is a variable which tells the economic status of a person and is measured in PKR.

Landholding: Land holding is variable that shows if a respondent has land or not and how much. Land holding is measured in acres.

Marital Status: Marital status is a binary variable with 1 value if a respondent is married and 0 value if a respondent is single. 
Household Size: Household size is taken as an important indicator of migration intention of a person so the size of the household tells the number of family members of the respondents residing in a house.

Health Facilities: Satisfaction level from health facilities tells that how much a respondent is satisfied with health facilities available to him at the place of his residence. It is measured through percentage.

Job Facilities: Satisfaction level from health facility tells that how much a respondent is satisfied with job facilities available to him at his living place. Satisfaction from job facility is measured in terms of percentage.

Transportation Facilities: Satisfaction level from transport facilities tells that how much a respondent is satisfied with transportation facilities available to him at his residence place and is also measured in terms of percentage.

Education Facilities: Satisfaction level from education facilities tells that how much a respondent is satisfied with educational facilities available to him at his residence place and is also measured in terms of percentage.

Business Facilities: Satisfaction level from business facilities shows that how much a respondent is satisfied with business facilities available to him at his residence place and is measured in terms of percentage.

Table 1: Details of Variables Used in the Study

\begin{tabular}{lll}
\hline Name & Dependent/Independent & Explanation \\
\hline $\mathrm{Y}$ & Dependent variable & Intention to migrate in binary response (Yes=1, No=0) \\
$\mathrm{X} 1$ & Independent variable & Income per year (000 PKR) \\
$\mathrm{X} 2$ & Independent variable & Family asset (000 PKR) \\
$\mathrm{X} 3$ & Independent variable & Already migrated (Y=1, N=0) \\
$\mathrm{X} 4$ & Independent variable & Landholding (Acres) \\
$\mathrm{X}$ & Independent variable & Marital status (Single1, Married=0) \\
$\mathrm{X} 6$ & Independent variable & Education (Schooling year) \\
$\mathrm{X} 7$ & Independent variable & Age (Years) \\
$\mathrm{X} 8$ & Independent variable & Household size (Family members). \\
$\mathrm{X} 9$ & Independent variable & Region (Urban=1, Rural=0). \\
$\mathrm{X} 10$ & Independent variable & Already migrated members of household \\
$\mathrm{X} 11$ & Independent variable & Satisfaction level from transportation facilities \\
$\mathrm{X} 12$ & Independent variable & Satisfaction level from health facilities \\
$\mathrm{X} 13$ & Independent variable & Satisfaction level from education facilities \\
$\mathrm{X} 14$ & Independent variable & Satisfaction level from security \\
$\mathrm{X} 15$ & Independent variable & Satisfaction level from job facilities \\
$\mathrm{X} 16$ & Independent variable & Satisfaction level from business facilities \\
\hline & &
\end{tabular}

Source: Author's Calculations

\section{Results and Discussion}

The socio-economic characteristics of sampled respondents are very diverse and dynamic. The study shows that out of 350 sampled respondents 173 young people have no migration intention and only 177 people have migration intentions from rural to an urban area and from urban to urban areas. Data revealed the fact that 182 respondents have no asset and 168 respondents have assets of different values. Respondents who belong to rural areas are 140 and
210 respondents belong to urban areas out of 350 total respondents. About land holding, the data shows that 196 respondents have no land while 154 respondents have land from 2 to 60 acres. Marital status data shows that 309 respondents are married and 41 respondents are unmarried. Residential status shows that 135 respondents belong to urban area and 215 respondents belong to rural areas. Qualification data of sampled respondents shows that only 2 respondents are uneducated and 348 respondents are having schooling 
years from 1 to 18 years. Satisfaction level from transport facilities tells that only 8 respondents are not satisfied with transport facilities while 342 respondents are satisfied with 10 to 100 percent level of satisfaction. Household data shows that there are 2 to 20 members in sampled respondent's families. Health satisfaction level shows that 6 respondents are unsatisfied with health facilities while 344 respondents are satisfied with health facilities from 20 to 100 percent. Education facilities data shows that 4 respondents are not satisfied with the education facilities given in their area and 346 are satisfied from 10 to 100 percent. Satisfaction level from security shows that 8 people are not satisfied with securities services, 342 respondents are satisfied 15 to 100 percent. Data on satisfaction level from job facilities shows that 6 respondents are not satisfied with job facilities while 344 respondents are satisfied with job facilities 8 to 100 percent. Data of satisfaction from business facilities reveals that 17 respondents are unsatisfied with business facilities in their area while 333 respondents are satisfied 10 to 95 percent. Distribution of socio-economic and demographic characteristics has been made in order to have deep insight about sampled respondents. On the bases of these characteristics migration intention among the youth of Khushab district has been observed and analyzed.

Income Distribution of Respondents: Data on the distribution of income shows that out of 133 respondents who have zero income, 20 respondents don't have the intention to migrate while 113 respondents have the intention to migrate. Out of 98 respondents who have income range (9-25) thousand, 37 respondents have no intention of migration and 61 respondents have the intention to migrate. Data reveals that increasing income level decreases the intention of migration among youth as shown in Table 2.

Table 2: Distribution of Income of Sampled Respondents

\begin{tabular}{lccc}
\hline Distribution of Income/per month & \multicolumn{2}{c}{ Intention to Migrate } & \\
\cline { 2 - 3 } (Thousand rupees) & No & Yes & Total \\
\hline No income & 20 & 113 & 133 \\
$9-25$ & 37 & 61 & 98 \\
$26-50$ & 86 & 3 & 89 \\
$51-75$ & 9 & 0 & 9 \\
$76-100$ & 16 & 0 & 16 \\
$101-125$ & 2 & 0 & 2 \\
$126-150$ & 3 & 0 & 3 \\
Total & 173 & 177 & 350 \\
\hline
\end{tabular}

Distribution of Respondents According to Assets: As shown in Table 3, out of 178 respondents who don't have any kind of assets, 12 respondents have no intention of migration while 166 respondents have the intention of migration. Out of 40 respondents who have assets amount in rupees from 50 thousand to one lack and fifty thousand, 32 respondents have no intention of migration and 8 respondents have an intention to migrate. Data of 350 respondents shows that intention to migration among youth decreases with increasing assets. 
Table 3: Distribution of Assets of Sampled Respondents

\begin{tabular}{lccc}
\hline \multicolumn{1}{c}{$\begin{array}{c}\text { Distribution of Assets } \\
\text { (Thousand rupees) }\end{array}$} & \multicolumn{2}{c}{ Intention to Migrate } & Total \\
\cline { 2 - 3 } & No & Yes & 178 \\
\hline No Assets holding & 12 & 166 & 40 \\
$50-150$ & 32 & 8 & 51 \\
$151-300$ & 50 & 1 & 46 \\
$301-450$ & 44 & 2 & 33 \\
$451-600$ & 33 & 0 & 2 \\
$751-900$ & 2 & 0 & 350 \\
Total & 173 & 177 & \\
\hline
\end{tabular}

Source: Author's Calculations

Distribution of Age: Relationship between age and intention to migration among youth states that out of 78 respondents who have age ranged (15-17 years), only13 respondents have no intention of migration while 65 respondents have an intention to migration. Out of 105 respondents who are of age from 18 to 20 years, 45 respondents have no intention of migration and 60 respondents have an intention to migrate. Out of 46 respondents having age range 21 to 23 years, 21 respondents have no intention of migration and 25 respondents have an intention to migration as shown in Table 4.

Table 4: Distribution of Respondents by Age

\begin{tabular}{lccc}
\hline $\begin{array}{l}\text { Distribution of Age } \\
\text { (Years) }\end{array}$ & \multicolumn{2}{c}{ Intention to Migrate } & \\
\cline { 2 - 3 } & No & Yes & Total \\
\hline $15-17$ & 13 & 65 & 78 \\
$18-20$ & 45 & 60 & 105 \\
$21-23$ & 21 & 25 & 46 \\
$24-26$ & 66 & 23 & 89 \\
$27-29$ & 28 & 4 & 32 \\
Total & 173 & 177 & 350 \\
\hline
\end{tabular}

Source: Author's Calculations

Distribution of Business Facilities: A total of 11 members are not satisfied and they all have the intention to migrate. Only one member wants to migrate who have satisfaction from business facilities from $10 \%$ to $25 \%$. Only 79 respondents who have satisfaction between $26-50 \%$, have the intention of migration. Respondents who have $76 \%$ to $100 \%$ level of satisfaction are 152 parts. Among those, 146 members have no intention of migration while only 6 members have the intention to migrate as shown in Table 5. 
Table 5: Distribution of Business Facilities of Sampled Respondents

\begin{tabular}{|c|c|c|c|}
\hline \multirow[t]{2}{*}{ Business Facilities (\%) } & \multicolumn{2}{|c|}{ Intention to Migrate } & \multirow[b]{2}{*}{ Total } \\
\hline & No & Yes & \\
\hline Not satisfied & 0 & 11 & 11 \\
\hline $10-25$ & 0 & 1 & 1 \\
\hline $26-50$ & 0 & 79 & 79 \\
\hline $51-75$ & 27 & 80 & 107 \\
\hline 76-100 & 146 & 6 & 152 \\
\hline Total & 173 & 177 & 350 \\
\hline
\end{tabular}

Source: Author's Calculations

Distribution of Job Facilities: Data shows that out of 11 members who are not satisfied with job facilities available to them, 8 members have no intention of migration while 3 members have an intention to migrate. Only 1 member has satisfaction level 10 to $25 \%$ and he does not want to migrate. Out of 79 members who have $26 \%$ to $50 \%$ level of satisfaction from job facilities, 69 members don't want to migrate and 10 members want to migrate. Out of 107 members who have 51 to $755 \%$ level of satisfaction, 77 members don't want to migrate while 30 members have an intention to migrate. Similarly, out of 152 respondents who have 76 to $100 \%$ level of satisfaction, 144 respondents have no intention of migration on the other hand 8 respondents want to migrate as shown in Table 6.

Table 6: Distribution of Job Facilities of Sampled Respondents

\begin{tabular}{lccc}
\hline \multirow{2}{*}{ Job facilities (\%) } & \multicolumn{2}{c}{ Intention to Migrate } & Total \\
\cline { 2 - 3 } & No & Yes & 135 \\
\hline Not satisfied & 8 & 127 & 97 \\
$10-25$ & 69 & 28 & 63 \\
$26-50$ & 52 & 11 & 52 \\
$51-75$ & 43 & 9 & 3 \\
$76-100$ & 1 & 2 & 350 \\
Total & 173 & 177 &
\end{tabular}

Source: Author's Calculations

\section{Descriptive Analysis}

Data shows that on average 50.6 percent of people have the intention to migrate from rural to urban and urban to urban migration with a standard deviation of 0.50068 . On an average income of the respondents is 21.8759 rupees per month. Minimum income is 8 thousand and a maximum of 150000 per month with a standard deviation of 27.07338. The mean of assets holding by the respondents is of value 152.19 rupees, with minimum 0.000 rupees and maximum 800000 rupees. The average number of already migrated respondents is 0.9143 members, with maximum 1 member and minimum 0 people. An average landholding of respondents is 9.00 acres. Whereas minimum land is 0 acre and maximum landholding is 60 acres.

Marital status shows that on average .6743 with a standard deviation of 0.46931 respondents are married. An average year of education of respondents is 13 years whereas maximum years of education 18 years and minimum years of education of respondents are 0 . The average household size is 8 members in a house while minimum household members are 2 and maximum 20 members. Average age of the respondents is 21.1857 years. Whereas the maximum age is 29 years and the minimum age is 15 years. Already migrated friends and family are 0.6629 members. Similarly, maximum members which have already been migrated are 4 and minimum 0 members. 
The average of the rural and urban regions shows 0.4000 members. The average of satisfaction from transportation facilities tells that 66.1600 people are satisfied with transport facilities with minimum and maximum $100 \%$.

The maximum level of satisfaction from transport facilities is $100 \%$ and the minimum level of satisfaction is $0 \%$. The average level of satisfaction from health facilities tells that $68.10 \%$ people are satisfied with the availability of health services in their region. A minimum level of satisfaction from health facilities is $0 \%$ and the maximum level is $100 \%$ and standard deviation 21.36512. The average satisfaction level from education facilities reveals that 72.1657 respondents are satisfied with education facilities available to them, whereas a maximum level of satisfaction is $100 \%$ and the minimum level is $0 \%$. The average level of satisfaction from security services is $70.3914 \%$ while minimum level of satisfaction from security is $0 \%$ and maximum level of satisfaction is $100 \%$. The average satisfaction level from job facilities reveals the satisfaction level of $68.5857 \%$. While the maximum level of satisfaction is $100 \%$ and minimum level of satisfaction is $0 \%$ with a standard deviation of 21.12471. Similarly, the average level of satisfaction from business facilities tells $68.5857 \%$. The minimum level of satisfaction from the business is $0 \%$ and maximum level of satisfaction is $100 \%$ with a standard deviation of 21.12664 as shown in Table 7.

Table 7: Descriptive Statistics of Sampled Respondents

\begin{tabular}{lllllc}
\hline Variables & $\mathbf{N}$ & Minimum & Maximum Mean & Std. Deviation \\
\hline Intention of migration & 350 & .00 & 1.00 & .5057 & .50068 \\
Income & 350 & 8.00 & 150.00 & 21.8759 & 27.07338 \\
Asset & 350 & .00 & 800.00 & 152.19 & 190.24756 \\
Already migrated & 350 & .00 & 1.00 & .9143 & .28034 \\
Land & 350 & .00 & 60.00 & 9.0000 & 14.20178 \\
Marital status & 350 & .00 & 1.00 & .6743 & .46931 \\
Education & 350 & .00 & 18.00 & 12.9000 & 2.28957 \\
Age & 350 & 15.00 & 29.00 & 21.1857 & 3.92878 \\
Household size & 350 & 2.00 & 20.00 & 7.9029 & 3.66690 \\
Region & 350 & .00 & 1.00 & .4000 & .49060 \\
Already migrated & 350 & .00 & 4.00 & .6629 & .96681 \\
Satisfaction from transportation facilities & 350 & .00 & 100.00 & 66.1600 & 26.70592 \\
Satisfaction from health facilities & 350 & .00 & 100.00 & 68.1000 & 21.36512 \\
Satisfaction from education facilities & 350 & .00 & 100.00 & 72.1657 & 19.43635 \\
Satisfaction from security services & 350 & .00 & 100.00 & 70.3914 & 24.68677 \\
Satisfaction from job facilities & 350 & .00 & 100.00 & 68.5571 & 21.12471 \\
Satisfaction from business facilities & 350 & .00 & 100.00 & 68.5857 & 21.12664 \\
\hline
\end{tabular}

Source: Author's Calculations

\section{Results of Regression Coefficients}

An extensive diagnostic study shows that this model is appropriate in explaining the impact of different variables on the migration intention of youth in district Khushab. Results obtained from the binary logistic regression model as shown in Table 8 state that one unit increase in income will decrease the intention. The value of the odds ratio of income shows that if the income of the respondent is increased by one thousand rupees then there are 0.86 times fewer chances that the respondent will have the intention to 
migrate. The results are inconsistent with the study of Lucas, (1985) who analyzed the correlation of migration intention, wage differential and employment opportunities in Botswana. This study reveals that there is a negative relationship between income and intention to migration, showing that higher income in the urban area will decrease the probability to migrate in cities, as farms and land owners have emotional attachment to their land. Already migrated friends and relatives urge people to move towards cities and other countries so that they can also get a high income and improve their living standards. Our analysis of already migrated friends and relatives show that one unit increase in already migrated friends and relatives will increase intentions to migrate. The estimated odd ratio of already migrated friends and family shows that if already migrated friend increases by one person then there are 204.6 times higher chances that the respondent will have an intention of migration. The results a line with a report (Hossain, 2001) which also depicts the positive relationship between migration decisions and relatives already migrated in the destination region.

Table 8: Results of Coefficients of Migration Intention

\begin{tabular}{lllllc}
\hline Variables & B & S.E. & Wald & Sig. & Odd Ratio \\
\hline Constant & 11.574 & 4.677 & 6.125 & $.013^{*}$ & 1.06300 \\
Income & -.149 & .075 & 3.971 & $.046^{*}$ & .862 \\
Assets & -.007 & .008 & .852 & .356 & .993 \\
Already migrated members & 2.269 & 2.489 & .831 & .362 & 9.674 \\
Land size & -.335 & .125 & 7.205 & $.007 * *$ & .715 \\
Marital status & -1.730 & 1.489 & 1.350 & .245 & .177 \\
Education & .991 & .523 & 3.585 & .058 & 2.694 \\
Age & -.508 & .248 & 4.210 & $.040^{*}$ & .602 \\
Household size & .801 & .339 & 5.578 & $.018^{*}$ & 2.228 \\
Region & 4.131 & 1.827 & 5.113 & $.024 *$ & 62.250 \\
Friends and family in other cities & 5.321 & 2.502 & 4.525 & $.033^{*}$ & 204.684 \\
Satisfaction from transport facilities & -.109 & .078 & 1.925 & .165 & .897 \\
Satisfaction from health facilities & -.092 & .043 & 4.647 & $.031 *$ & .921 \\
Satisfaction from education facilities & -.248 & .077 & 10.538 & $.001 * *$ & .780 \\
Satisfaction from Security & .072 & .058 & 1.512 & .219 & 1.074 \\
Satisfaction from Job facilities & -.595 & .263 & 5.118 & $.024 *$ & .551 \\
Satisfaction from business facilities & -.187 & .058 & 10.568 & $.001 * *$ & .829 \\
\hline \multicolumn{2}{l}{ Source: Author's Calculations } & &
\end{tabular}

As already migrated relatives provide residence facilities and guidelines about the employment opportunities and some financial assistance to newly migrated relatives. Landholding by respondents shows that one unit increase in land size decreases the intention to migrate. The estimated odd ratio of land size reveals that if the land size of the respondent increases by one acre then there are 0.72 times fewer chances that the respondent will have the intention to migrate. The obtained result is matched with Nabi \&Worsfold (1986) who analysed Pakistan's rural to urban migration using the probit model and suggested that land size, the value of output and tenure system are some important factors of migration decision. The coefficient of marital status shows that one unit increase in married person will decrease the migration intention. However, the results are not significant.
This analysis is supported with the analysis of international migration which concluded that married couple with adult children has altruistic intentions towards migration; they also emphasized negative migration intention of a married couple who have school-going children.

One unit increase in age will decrease the probability of migration intention on average by 0.508 units. The corresponding valve of odd ratio states that if the age of the respondents increases by one year then there are 0.62 times fewer chances that the respondent will have the intention to migrate. The obtained result is significant with (.040) significance level. One unit increase in assets holding will decrease the probability of intention to migration by 0.007 units on average. However, the obtained results are not significant. These results are matched with the study conducted by 
Crivello (2011). Similarly, one unit change in education will increase the probability of intention to migration by 0.991 units on average with $(0.058)$ significance level. The corresponding value of odd ratio shows that if the education of the respondent increases by one year then there are 2.69 times higher chances that the respondent will have the intention to migrate. This result is consistent with the study (Caldwell, 1968) which reported that in Ghana, there was a positive association between the level of education attained and intention to migration but this relationship is nonlinear. The study is also supported by the Kasimis (2005) who analysed that in south European rural areas most of the migrating young generation have high education and low-income level so they moved to get high income in the urban area. Household size is another important indicator of migration intention. One unit increase in household size will increase the probability of migration among youth by 0.801 units on average. The estimated odd ratio of household size shows that if the household size increases by one member then there are 2.23 times higher chances that the respondents will have an intention to migrate. The obtained result is highly significant (0.018). The result is similar to the study conducted by a group of researchers (Connell, 1976; Sekhar, 1993; Hossain, 2001; and Sormani et al., 2008). They concluded that in a large family it becomes easy for the family to decide which family member should migrate and to whom should stay back to take care rest of the family members and old parents.

Already migrated members of the household have a positive influence on migration intention among the other household members. The result shows this phenomenon such as one unit increase in already migrated members of the household will increase the probability of migration intention by 2.269 units. However, the obtained results are not significant. The study is matched with an analysis of (Agesa and Kim, 2001). They used a simple expected utility model of the household to find the determinants of family and split migration in Kenya. Split migration happens when the household head moves first from rural to urban area and then the rest of the family moves. When all the family members move together then family migration occurs. This theoretical model then was tested while collecting the data taken from Kenya. The results supported the predictions of the model and argued that split migration occurs when there are a large number of household dependents. One unit change in satisfaction level from transport facilities will change the probability of migration by 0.084 units on average, with (0.109) level of significance. One unit increase in health facilities will decrease the probability to migrate by .092 units on average with a significance level of 0.031 . The corresponding value of odd ratio shows that if health facilities are increases by one percent then there are 0.92 times fewer chances that the respondent will have the intention to migrate. One unit increase in satisfaction level from education facilities will reduce the probability of migration on average by 0.248 units. The estimated odd ratio reveals that if satisfaction from education facilities increases by one percent then there are 0.78 times fewer chances that the respondent will have the intention to migrate. Obtained results are consistent with the deep study of Pretty (2003) who investigated that lack of educational and employment opportunities in urban areas stimulate young rural people to migrate towards cities to get higher education and employment facilities. One unit increase in satisfaction level from security will change the probability of youth migration by .072 units on average. But the obtained result is not highly significant. One unit increase in the level of satisfaction from job facilities will reduce the probability to migrate on average by 0.595 units. The value of odd ratio reveals that if satisfaction from job facilities of the respondent is increased by one percent then there are 0.55 times fewer chances that the respondents will have the intention to migrate. One unit increase in satisfaction level from business facilities will change the probability to migrate by 0.187 units. The odd value of satisfaction from business facilities reveals that if the satisfaction of respondents from business facilities increases by one percent then there are 0.83 times fewer chances that the respondent will have the intention to migrate. The result matches the study analysis of some researchers (Pun et al., 2010 and Jacka, 2006). Their qualitative research highlighted the importance of economic incentives of the youth migration decision and different examples of migration-related factors such as in search of job and employment opportunities to get rid of poverty and to raise income to start a business in the future. They also revealed the fact that people migrate to large cities to expand their business, as it is not possible to manage and to expand business size while living in small towns.

\section{Conclusions}

The results obtained from this study show that there are some economic and non-economic pull and push factors that aspire the young generation to migrate from rural to urban and urban to urban areas. There is a negative relationship between the coefficient of income and intention to migration and odd ratio with significant effect, showing that people who earn high income in the rural areas will not migrate towards cities. So in order to reduce migration intention government should regulate reforms regarding the distribution of resources to increase incomes of rural residents. The negative sign of the 
coefficient of land size of respondents and value of odd ratio with significant effect shows that increasing land size decreases the intention to migrate as rural residents have an emotional attachment with their land and they are not ready to leave their land. Hence migration intention could retard with favorable land reforms by the government. The result of the coefficient of age shows a negative sign and odd ratio with a significant effect which reveals that teenagers are more likely to have migration intention. The majority of young respondents have the intention of migration in the Khushab district. As young people have updated knowledge and innovative skills so they are pivot resources of economic growth and development, therefore to reduce migration intention among youth institutional and legislative framework should organize to encourage and promote youth.

Household size has a significant and positive relationship with the intention of migration. As the number of family members increases the decision that which family member will move and who will stay back at home for taking care of the rest of the family members become easy. Therefore in order to reduce migration intention government should make policies and programs regarding family planning on modern lines. Results regarding region show that rural residents have more eager to migrate as compare to urban residents due to slum residence and limited or absences of resources, therefore policies should be made regarding the problem of congested residence of people in a rural area by new opening the area where there is still a low population and decentralization of social services from the urban area to the rural area so that intentions of rural resentments to migrate in an urban area for availing services might be reduced. Friends and family in other cities also have significant effects on the intention to migrate among youth. They provoke their intention by telling them job opportunities and providing them initial financial support as well as residence facilities, therefore rural youth should be targeted with the provision of favorable environment and residence facilities along with job opportunities, in this way they will not be attracted by their friends and family residing in the urban region. Results show that social services such as health facilities also have a significant and negative impact in determining youth's intention to migration, therefore the government should have a focus in organizing, extending and improving social services such as availability health of care centers in rural areas so that satisfaction from health facilities can be increase.

Satisfaction from educational facilities has a significant and negative role in the intention of migration among rural youth. It is suggested that initiative regarding higher educational institutions in rural regions should take so that young people alter their intention to migrate toward urban areas for getting a higher education. In this regard, another measure is to improve the educational system and providing agricultural education to youth so that they can work in farms efficiently and can earn income while living in their place of origin. Results of satisfaction from job facilities also have a significant and negative impact on intention to migration among the youth of Khushab district, so government should take some strong measures for the provision of job facilities to rural residents to the best possible nearest place to their homes and the best possible socioeconomic facilities to them so that their satisfaction level from job facilities can be enhanced and their migration intentions might alter. In this way, migrants who are jobless in urban areas can be encouraged and even forced to rural areas. Satisfaction from business facilities also have a significant and negative effect on the intention to migration among youth, implies that if people have satisfied level of business facilities in the rural area they will not migrate toward urban areas, therefore innovative business ideas and facilities should be introduced by the policymakers to the young generation in rural areas to enhance their satisfaction level from business facilities.

\section{References}

Abdel-Hamid, N.M., 2009. Premalignant variations in extracellular matrix composition in chemically induced hepatocellular carcinoma in rats. Journal of Membrane Biology, 230(3), 155-162.

Agesa, R.U., Kim, S., 2001. Rural to urban migration as a household decision: evidence from Kenya. Review of Development Economics, 5(1), 60-75.

Austin, J., Richert, A., 2005. Patterns of habitat use by whooping cranes during migration: Summary from 1977-1999 site evaluation data. Proceedings North American Crane Work-shop 9: 79-104

Boyd, M., 1989. Family and personal networks in international migration: recent developments and new agendas. International Migration Review, 23(3), 638-670.

Caldwell, J.C., 1968. Determinants of rural-urban migration in Ghana. Population Studies, 22(3), 361-377.

Connell, J., 1976. Migration from rural areas: the evidence from village studies. Delhi: Oxford University Press.

Crivello, G., 2011. Becoming somebody: youth transitions through education and migration in Peru. Journal of Youth Studies, 14(4), 395-411.

De Jong, G.F., 2000. Expectations, gender, and norms in migration decision-making. Population Studies, 54(3), 307-319.

De Jong, G.F., Root, B.D., Gardner, R.W., Fawcett, J.T. and Abad, R.G., 1985. Migration intentions and behaviour: decision making in a rural 
Philippine province. Population and Environment, 8, 41-62.

Epstein, G.S., Gang, I.N., 2006. The influence of others on migration plans. Review of Development Economics, 10(4), 652-665.

Harris, J.R., Todaro, M.P., 1970. Migration, unemployment and development: a two-sector analysis. The American Economic Review, 60(1), 126-142

Holst, E., Schrooten, M., 2006. Migration and money: What determines remittances? Evidence from Germany (No. 566). DIW Discussion Papers.

Hossain, M.Z., 2001. Rural-urban migration in Bangladesh: a micro-level study. In Brazil IUSSP conference. August (pp. 20-24).

Huggins, C., Musahara, H., Kamungi, P.M., Oketch, J.S., Vlassenroot, K., 2005. Conflict in the great lakes region-how is it linked with land and migration?. ODI: Natural Resource Perspectives, $96,1-4$.

Jacka, T., 2006. Rural women in urban China: gender, migration and social change. Armonk, NY: M.E. Sharpe

Kasimis C. 2005. Migrants in the Rural Economies of Greece and Southern Europe. Migration Information Source, 1/10/2005. Available at http://www.migrationinformation.org.

Kloep, M., Hendry, L.B., Glendinning, A., Ingebrigtsen, J.E., Espnes, G.A., 2003. Peripheral visions? A cross-cultural study of rural youths' views on migration. Children's Geographies, 1(1), 91-109.

Kotkin, J., Modarres, A., Cox, W., .2013. Retrofitting the dream: housing in the 21 st Century. Pinatubo Press.

Kugelman, M. 2014. Understanding Pakistan's unstoppable urbanization. In M. Kugelman (Ed.), Pakistan's runaway urbanization: What can be done? (pp. 1-20). Washington, DC: Woodrow Wilson International Center

Lucas, R. E., 1985. Migration amongst the Batswana. The Economic Journal, 95(378), 358-382.

Macharia, K., 2003. Migration in Kenya and its impact on the labor market. In Conference on African Migration in Comparative Perspective, Johannesburg, South Africa (pp. 4-7).

Nabi, A., Worsfold, P.J., 1986. Bioluminescence assays with immobilised bacterial luciferase using flow injection analysis. Analyst, 111(11), 13211324.
Parreñas, R., 2015. Servants of globalization: migration and domestic work. Stanford University Press.

Pretty, J., 2003. Social capital and the collective management of resources. Science, 302(5652), 1912-1914.

Pun, N., Chan, C.K.C., Chan, J., 2010. The role of the state, labour policy and migrant workers' struggles in globalized China. Global Labour Journal, 1(1), 132-151

Rodriguez, R.M., 2010. Migrants for export: how the Philippine state brokers labor to the world. University of Minnesota Press.

Roman, M., Vasilescu, M.D., 2016. Explaining the migration intentions of Romanian youth: are teenegers different. Romanian Statistical Review, 64(4), 69-86.

Root, B.D., De Jong, G.F., 1991. Family migration in a developing country. Population Studies, 45(2), 221-233.

Sekhar, T.V., 1993. Migration selectivity from rural areas: evidences from Kerala. Demography India, 22(2), 191-202.

Siddiqi, H.G., 2004. The Readymade garment industry of Bangladesh. University Press Limited.

Sormani, M.P., Tintorè, M., Rovaris, M., Rovira, A. Vidal, X., Bruzzi, P., Montalban, X., 2008. Will Rogers phenomenon in multiple sclerosis. Annals of neurology, 64(4), 428-433.

Sosne, G., Hafeez, S., Greenberry, A.L., KurpakusWheater, M., 2002. Thymosin $\beta 4$ promotes human conjunctival epithelial cell migration. Current Eye Research, 24(4), 268-273.

Stinner, W.F., Van, L.M., 1992. Community size preference status, community satisfaction and migration intentions. Population and Environment, 14(2), 177-195.

Tang, S., Hao, P., 2018. Floaters, settlers, and returnees: settlement intention and hukou conversion of China's rural migrants. China Review, 18(1), 11-34.

Wang, Y., Chen, D., Qian, H., Tsai, Y.S., Shao, S., Liu, Q., Dominguez, D., Wang, Z., 2014. The splicing factor RBM4 controls apoptosis, proliferation, and migration to suppress tumor progression. Cancer Cell, 26 (3), 374-389,

Yang, H., 2000. A comparative analysis of China's permanent and temporary migration during the reform period. International Journal of Social Economics, 27(3), 173-193. 